\title{
РАДИОСВЯЗЬ для Арктики
}

Е.Слодкевич, генеральный директор ООО "Фирма "Радиал" / radial@radial.ru

УДК 621.396, DOI: 10.22184/2070-8963.2022.101.1.50.51

Обосновывается целесообразность использования в условиях Арктики простой и доступной коротковолновой радиосвязи. Рассказывается о приложении "КВ-пейджер".

На фоне грандиозных технологических шагов в области спутниковой телефонии, основанной на инфраструктуре планетарного масштаба с глобалистским подходом операторов связи, сегодня почему-то все забыли об очень простой, дешевой и доступной коротковолновой радиосвязи, не требующей ничего, кроме компактной радиостанции и антенны. А ведь именно связь внутри сообщества (оленеводов, туристов, спасателей, рыбаков, охотников и т.п.) может послужить залогом безопасности в условиях Арктики.

Формирование такой радиосферы над зоной работы радиостанции, а это территория с радиусом примерно 150-200 км, позволит быть постоянно в курсе событий, происходящих на рыболовецких тонях, в охотничьих избушках, в глубине заповедника или национального парка.

"Василий, там наш УАЗик не проезжал?" моментально раздается на кордоне из громкоговорителя дежурного инспектора голос главного охотоведа. "Да, Михалыч, полчаса уже как мимо нас просвистел!"

Или: "Мы тут чувствуем запах дыма, ветер восточный, пусть самолет лесавиаохраны пролетит над нами, явно где-то лес горит," - передали московские туристы в местном радиоканале. Для этого не нужно знать и набирать номер телефона. Все, кто тебя слышат, обязательно отреагируют. Не нужно быть чьим-то абонентом и оплачивать трафик, достаточно иметь радиостанцию с лицензией. Нажал клавишу передачи и тебя все слышат.

Сегодня на рынке представлено большое количество радиостанций, но я обращу внимание на рации производства "Радиал", имеющие простейшее управление. Одна из них - это радиостанция "Карта-3". Ее особенностью является возможность работы в цифровом режиме программы "КВ-пейджер". Это значит, что нет необходимости дежурить на радиостанции сообщение примет подключенный к ней компьютер или смартфон. Они же и подтверждение о приеме отправят. Передать координаты и посмотреть их на офлайн-картах также можно с помощью приложения "КВ-пейджер". Это особенно удобно, когда жители, например кочевники-оленеводы, разбросаны по обширным арктическим территориям. Передать сообщение для вызова санитарной авиации, о каком-то чрезвычайном происшествии или просто пообщаться с друзьями и "соседями" за 100 км - все это возможно с помощью двух небольших коробочек и антенны. Кстати, антенны нужны большие, длиной 20-30 м. Но в тундре место для них

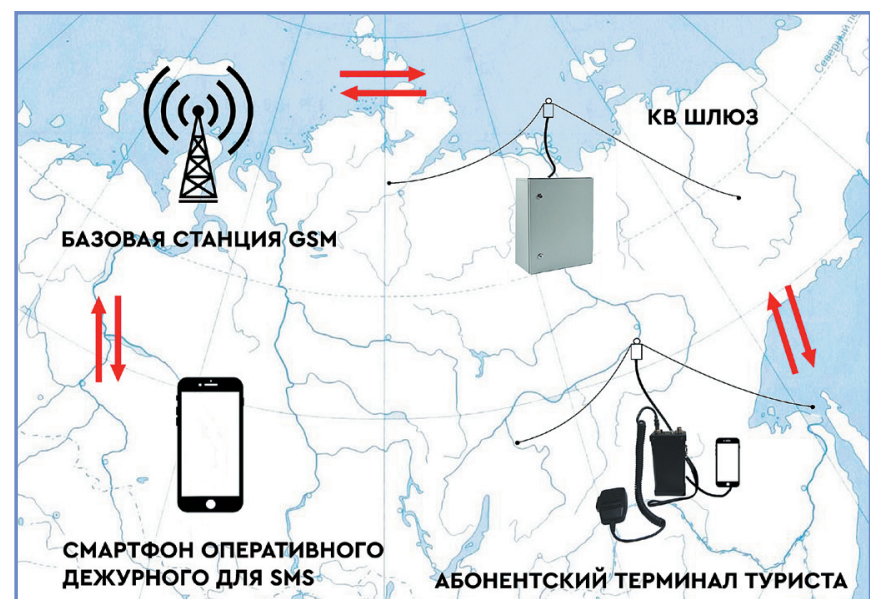


найдется. Почему такие большие? Потому что для радиосвязи на такие дистанции используется диапазон частот 2-4 МГц, и полуволновые укороченные диполи получаются как раз таких размеров.

Что еще можно получить с применением коротких волн? Если установить дополнительное устройство - КВ-шлюз - в районе действия сотовой сети, то можно увеличить зону ее обслуживания по передаче SMS на те самые 150-200 км. A также транслировать свои координаты или трек маршрута в сеть Интернет. Можно запрашивать и получать прогноз погоды на конкретное место своего расположения, используя функцию погодного информатора. Для Арктики это особенно актуально, ведь все передвижения и работы планируются в зависимости от того, будет метель или нет.

В чем же особенность такой цифровой передачи, чем она привлекательна? Благодаря очень узкой полосе сигнала, подобно старой доброй "морзянке", сигнал КВ-пейджера требует гораздо меньше энергии передатчика, что позволяет использовать легкие радиостанции, и запаса батарей хватает надолго. Кроме того, этот сигнал обладает высокой помехозащищенностью и декодирующий его смартфон (конечно же, без SIM-карты) вытягивает полезную информацию даже когда сигнал совсем не слышен ухом!

Ознакомиться с большими возможностями наших разработок вы можете по приведенным ниже QR-кодам.
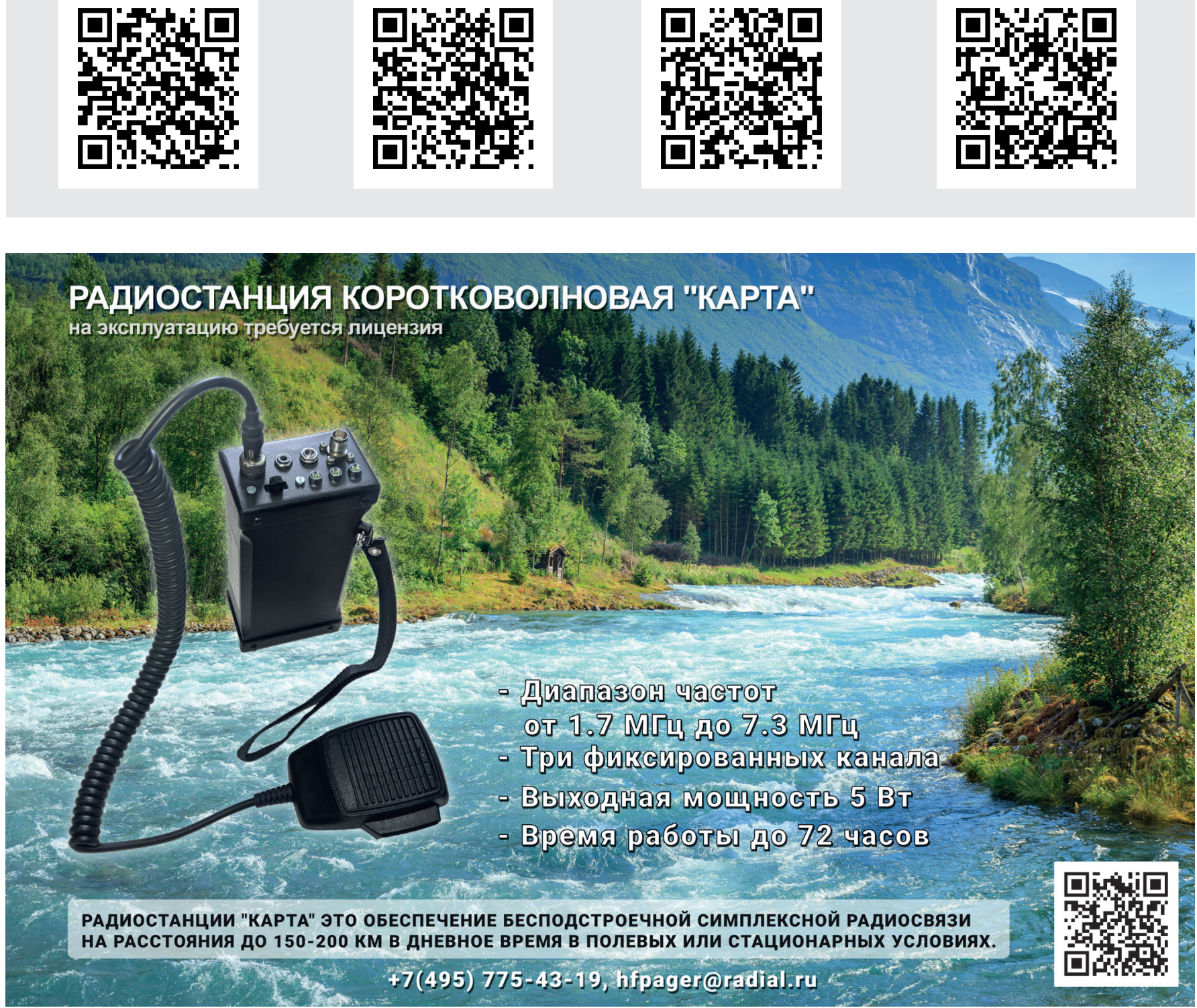